\title{
The Oman Animal and Plant Genetic Resources Center's (OAPGRC) Science Café: A Success Story
}

\author{
Dr. Nadiya Abubakr Al Saadi, Dr. Hameed Challoob Ali Al- \\ Khafaji*, Rasha Hilal Al Saifi \\ Oman Animal \& Plant Genetic Resources Center \\ *Corresponding Author: Hameed Challoob Ali Al-Khafaji, email: \\ hamid_chaloub@hotmail.com
}

\section{Citation: Al Saadi N. A., Al- Khafaju H. C. A., Al Saifi R. H. (2017) The Oman Animal and Plant Genetic Resources Center's (OAPGRC) Science Café: A Success Story, Open Science Journal 2(4).}

Received: $26^{\text {th }}$ May 2017.

Accepted: $5^{\text {th }}$ July 2017.

Published: $24^{\text {th }}$ October 2017.

Copyright:@ 2016 This is an open access article under the terms of the Creative Commons Attribution License, which permits unrestricted use, distribution, and reproduction in any medium, provided the original author and source are credited.

Funding: The author(s) received no specific funding for this work.

Competing Interests: The author have declared that no competing interests exists.

\begin{abstract}
Science Cafés are held in many towns and cities across the world for the promotion of scientific culture and the understanding of our daily lives, which we live in. They provide a platform for interaction and dialogue between scientists, researchers, businesses and the community on trends towards current scientific issues the extent of their impact on culture and society. The Oman Animal and Plant Genetic Resources Center (OAPGRC) Science Cafe is a forum for the discussion of important and interesting scientific topics and issues. Since May 2013 to December 2015, OAPGRC has held a series of science café sessions on topics related to biodiversity, food security, climate change, pollution and sustainable use. The OAPGRC science café is the first in Oman to be put on the international map of scientific cafes around the world. Reviewing the data on the outcomes and performance of these sessions indicates that the session attendance and active participation was $51 \%$ by men and $49 \%$ women. This is an exceptional case where the interest is almost equal between the genders. As for the age group, the highest percentage $49 \%$ was of a class of young people aged between 18-25 years. Followed by the age group (26-35 years) which was $30 \%$. The lowest percentage was $21 \%$ for the age group of above 35 years. The experience of the science café in Oman has been proved as a major success for both the scientific and social aspects. Therefore there are different plans to maintained and develop it in the near future.
\end{abstract}

Keywords: Scientific, Café, OAPGRC, Success, Story 


\section{Introduction}

The science café format has spread across the global; adapting to different cultures and audiences. Duncan Dallas in Leeds, UK organized the first Science Café in 1998. Dallas was the founder of Café Scientifique (4) whose worldwide success has helped introduce science to millions of people at any age and stage of education. Dallas based the Science Cafe on the Café Philosophic movement developed by the French philosopher Marc Sauté. In France, science cafes were established by scientists who thought they ought to inform the public on the current scientific topics of concern. In the UK it was started by members of the public who wanted to know more about science. In both countries, they began within an academic structure and spread to more popular locations, and thereby attracted audiences. It started at a time in the UK where COPUS, the Committee on the Public Understanding of Science (organized by the Royal Society and the British Association for the Advancement of Science), considered that a better understanding of science was needed by the public. Newspapers considered it odd that people should go to a café, drink wine and discuss science rather than just a gossip (1).However, the public was becoming more concerned about topics like Mad Cow Disease, GM crops, Cloning, etc.

Science café is usually held in countries that support the scientific culture in everyday life. Where scientists, researchers and community all gather to share a two-way dialogue on the latest relevant scientific issues and their impact on culture and community. The issues discussed at Science Cafés are important topics that require awareness. The issues discussed are important and play a major, role in food, agriculture, and industrial security. Through supporting an entire global biodiversity. The purpose of Science Café is to address the major scientific, and social issues that are related to genetic resources, as well as discussed the means of maintaining them in order to serve the community and future generations.

Individual Cafes have many different names and often do not require funding; only payment for the speaker is travelling expenses, usually made through donations given by the audience. The Cafes provide the opportunity for individuals and groups to explore and discuss science through much different form, such as street scenes, comedy, music, theatrical readings, and demonstrations.

Public science initiatives are currently running in more than 40 towns across the United Kingdom and in many other countries around the world. At least twelve cafés outside the UK are organized by the British Council alone. A science café chain organized at schools called Junior Café Scientifique. (3)

Today, Science Cafes are organized in towns and cities across the world including Oman. (Diagram 1) 


\section{What is the OAPGRC Science Café and its objectives?}

The OAPGRC Science Cafe is a forum for the discussion of important and interesting scientific issues. We meet on a monthly basis and the sessions are informal, relaxed, fun and accessible. It's an opportunity to get together with old and new friends in a relaxed atmosphere and discuss cool scientific topics.

Our audience consists of people who are interested in science, but generally never have the opportunity to discuss with their views, and ask questions of, someone in the know. The Science Café panelists assume no scientific knowledge, so anyone can come along and participate

OAPGRC is determined to create awareness of the importance of genetic diversity in animals, plants, and microorganisms in Oman, as they are all considered as natural traditional resources. The Center's goal is to achieve excellence in the various fields related to genetic resources, ranging from education and scientific research to innovation and investment. (5)The main goals of the science café are to Create dialogue and communication between scientists, experts, and the community, to raise awareness of animal and plant genetic resources, microorganisms and marine life through experts in the fields of genetic resources, to start discussions about the challenges and opportunities of genetic resources and set up networks for knowledge exchange and top scientific practices in order to maintain genetic resources.

The Science café is one of the main achievements on awareness of the Center. In 2013, the first Science café was launched together with The Research Council (TRC), in order to pursue the goals of the center, the first sessions focused on establishing a platform for mutual learning and dissemination of knowledge and science in Oman. To our knowledge, this is the first example of a Science Café in Oman.Main operated sessions in Oman from 2013-2015 as per the schedule below ( Table1)

\section{Results and discussions}

Table (2) and Figure (1) shows the analysis of 11 sessions of Science Café during the period from 28 May 2013 to 30 December 2015. The results indicated that the Science Café introduces important topics to the community, such as the marine life, and other topics about the honey, which highlights the benefits of honey. Another successful topic was the importance of medicinal plants, and traditional medicines. An exceptional attendance was achieved, with a great diversity of audience with $51 \%$ of men and $49 \%$ for women participating. As for the age group, the youth (18-25 years) attendance was highest with $49 \%$. Followed by the age group (26-35 years) which was $30 \%$. The lowest percentage was $21 \%$ in the age group of above 35 .years.

Regarding the question, how did you hear about Science café? The options were through email, scientific speakers, and social Media MS, and other. The top percentage of $44 \%$ was through speakers, followed by Social Media with $31 \%$, then $22 \%$ for Email, $19 \%$ from SMS, and the other $18 \%$. 
The science cafés audience's occupation was also monitored, with the highest percentage being job seekers and students with $52 \%$. This statistic shows the usefulness in providing the latest information for their related studies. While for the public sector, the attendance percentage was $34 \%$, and $14 \%$ of the private sector.

Science Café of Oman Animal and Plant Genetic Resource Center has been successful in maintaining and developing the various genetic resources. The center was recently established by Sultan Qaboos's order, under the umbrella of TRC in 2012. The center's activities were highly recognized in spreading awareness in Oman's community, especially in sustainable development of genetic resources to support the food security. Furthermore, the opportunity for the use of resources in medical plant investment by producing medical drugs and pharmaceuticals.

From the above results, it turned out that the scientific café has achieved part of the goal of increasing the public awareness among the Omani society, especially the youth, to conserve the natural resources, particularly genetic resources, as they represent the basis of food security and protecting of the Omani environment.

The Sultanate of Oman was labeled on the map of science cafés around the world (2) as well as OAPGRC as a registered scientific institution that organizes the Science café every month and presents advanced science programs that offer the community needs, and spreads media awareness of animal and plant genetic resources together with other species. 
Table 1: The Main Operated sessions of Science Café held in Oman from May 2013 to December 2015. for English and Arabic sessions.

\begin{tabular}{|c|c|c|c|c|}
\hline & Topic & Date & Venue & Center help session \\
\hline 1 & $\begin{array}{l}\text { Biodiversity and Genetic } \\
\text { Erosion: A Game of } \\
\text { Consequences (Arabic session) }\end{array}$ & 28-May-2013 & $\begin{array}{l}\text { Bait Al B aranda } \\
\text { Museum }\end{array}$ & $\begin{array}{l}\text { 1. Pro.Othman Mahgoub,2.Dr.Ali } \\
\text { Al-Lawati, 3. Michel Claereoudt }\end{array}$ \\
\hline 2 & $\begin{array}{l}\text { Global Warming and Genetic } \\
\text { Resources: Are We Ready for } \\
\text { the Change?(English session) }\end{array}$ & 27-Sep-2013 & $\begin{array}{l}\text { Al Bustan Palace } \\
\text { Hotel }\end{array}$ & $\begin{array}{l}\text { 1. Dr.Salim K. Nadaf,2. Dr. Antoly } \\
\text { V Chernyshev, 3. Dr. ....... }\end{array}$ \\
\hline 3 & $\begin{array}{l}\text { Renewable Energy and } \\
\text { Biodiversity (English session) }\end{array}$ & 13-Nov-2013 & $\begin{array}{l}\text { Café' Barbera(Bait } \\
\text { Al Reem) }\end{array}$ & $\begin{array}{l}\text { 1. Dr. Amar Al.Obidani, 2.Dr. } \\
\text { Antoly V Chernyshev }\end{array}$ \\
\hline 4 & $\begin{array}{l}\text { Mammals Genetic Diversity: } \\
\text { Horses, Camels (Arabic } \\
\text { session) }\end{array}$ & 24-Feb-2014 & $\begin{array}{l}\text { Café' Barbera(Bait } \\
\text { Al Reem) }\end{array}$ & 1. Dr. Albano, 2. Ihab Shatt \\
\hline 5 & $\begin{array}{l}\text { You are what you eat. Food } \\
\text { for thought (English Session) }\end{array}$ & 1-Apr-2014 & $\begin{array}{l}\text { Al Mouj Golf } \\
\text { Restaurant }\end{array}$ & $\begin{array}{l}\text { 1.Dr. Ahmed Al. Shukaili,2. Mr. } \\
\text { Yahya Al. Mukhaini,3. } \\
\text { Dr.Mohammed Essa }\end{array}$ \\
\hline 6 & $\begin{array}{l}\text { Millennials and the future of } \\
\text { food (English Session) }\end{array}$ & 24-Sep-2014 & Oman Tel & $\begin{array}{l}\text { 1.Dr.Nejib Guizani,2.Mr.Robert } \\
\text { MacLean (NHI), 3. Sami Al- } \\
\text { Shaikh. }\end{array}$ \\
\hline 7 & $\begin{array}{l}\text { Microbial Genetic Resources } \\
\text { (The best things Come in } \\
\text { Small Packages). (English } \\
\text { Session) }\end{array}$ & 3-Dec-2014 & $\begin{array}{l}\text { Moka and More } \\
\text { coffee Shop }\end{array}$ & $\begin{array}{l}\text { 1.Dr. Saif Al- Bahri,2.Dr.Siva } \\
\text { kumar, 3.Mr. Nelesh Bakal }\end{array}$ \\
\hline 8 & $\begin{array}{l}\text { Oman's Marine Life: Plenty } \\
\text { More Fish in the Sea? (Arabic } \\
\text { Session) }\end{array}$ & 28-Jan-2015 & $\begin{array}{l}\text { Moka and More } \\
\text { coffee Shop }\end{array}$ & $\begin{array}{l}\text { 1.Dr.Shekar Bose,2. Abdesslam } \\
\text { Fahfouhi }\end{array}$ \\
\hline 9 & $\begin{array}{l}\text { Buy Local Supporting } \\
\text { Communities and Protecting } \\
\text { the Environment (English } \\
\text { session) }\end{array}$ & $27-05-2015$ & $\begin{array}{l}\text { Lulu Hyber } \\
\text { Market }\end{array}$ & $\begin{array}{l}\text { 1. Malik Al.Ghahdami,2. Dr. } \\
\text { Hameedichalloob, 3.Assad } \\
\text {....Al.Kindi }\end{array}$ \\
\hline 10 & $\begin{array}{l}\text { Solving Our Problems } \\
\text { Through STEM. (English } \\
\text { Session) }\end{array}$ & $28-10-2015$ & $\begin{array}{l}\text { Moka and More } \\
\text { coffee Shop }\end{array}$ & $\begin{array}{l}\text { 1. Mohammed Al.Magiri,2. Basel } \\
\text { Dhyani }\end{array}$ \\
\hline 11 & $\begin{array}{l}\text { Planting for the Future: } \\
\text { Native Plants in Our Gardens } \\
\text { (English Session) }\end{array}$ & $30-12-2015$ & $\begin{array}{l}\text { Sultan Qaboos } \\
\text { University }\end{array}$ & $\begin{array}{l}\text { 1. Dr.AbulAraheem Al-Ismaili,2. } \\
\text { Abdullbaqi Al.Raisi,3. Dr. } \\
\text { Abdullah Al-Jafari }\end{array}$ \\
\hline
\end{tabular}


Table 2: The data regarding the Science Café collected during the period from May 2013 December for English and Arabic sessions

\begin{tabular}{|c|c|c|c|c|c|c|c|c|c|c|c|c|c|c|}
\hline \multirow{2}{*}{ 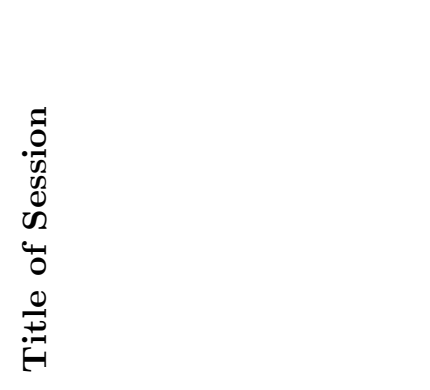 } & \multirow{2}{*}{ 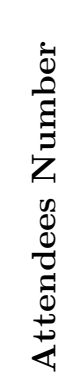 } & \multirow[b]{2}{*}{ 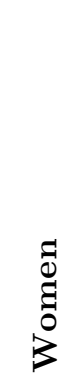 } & \multirow[b]{2}{*}{ 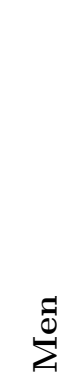 } & \multicolumn{3}{|c|}{ Age Group } & \multicolumn{5}{|c|}{$\begin{array}{c}\text { How did you hear about } \\
\text { Science Café? }\end{array}$} & \multicolumn{3}{|c|}{ Occupation } \\
\hline & & & & \begin{tabular}{c}
12 \\
\multirow{2}{1}{} \\
$\infty$ \\
-1
\end{tabular} & $\begin{array}{l}12 \\
0 \\
0 \\
\text { N }\end{array}$ & $\stackrel{20}{6}$ & ㅎี & 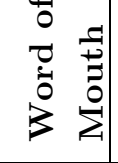 & 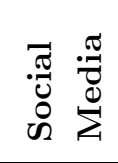 & $\sum_{\infty}^{\infty}$ & 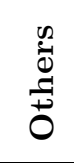 & $\begin{array}{l}5 \\
\dot{0} \\
0 \\
0 \\
0 \\
0\end{array}$ & 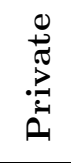 & 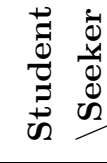 \\
\hline $\begin{array}{l}\text { Microbial Genetic } \\
\text { Resources } \\
\text { (English session) }\end{array}$ & 29 & 12 & 17 & 13 & 7 & 8 & 2 & 9 & 13 & 3 & 1 & 8 & 1 & 12 \\
\hline $\begin{array}{l}\text { Microbial Genetic } \\
\text { Resources (Arabic session) }\end{array}$ & 8 & 4 & 4 & 4 & 3 & 1 & 1 & 4 & 1 & 2 & / & 4 & / & 4 \\
\hline $\begin{array}{l}\text { Oman's Marine Life Plenty } \\
\text { More Fish in the Sea } \\
\text { (English session) }\end{array}$ & 25 & 7 & 18 & 3 & 10 & 12 & 9 & 7 & 5 & 4 & / & 6 & 7 & 6 \\
\hline $\begin{array}{l}\text { Oman's Marine Life Plenty } \\
\text { More Fish in the Sea } \\
\text { (Arabic Session) }\end{array}$ & 33 & 20 & 13 & 20 & 10 & 3 & 5 & 16 & 5 & 1 & 6 & 9 & 2 & 18 \\
\hline $\begin{array}{l}\text { Another Treasure from } \\
\text { Oman (The Honey) } \\
\text { (Arabic Session) }\end{array}$ & 14 & 9 & 5 & 11 & 3 & / & 1 & 1 & 3 & 1 & 7 & 1 & 2 & 5 \\
\hline $\begin{array}{l}\text { Dose of Our Medicine } \\
\text { (Arabic Session) }\end{array}$ & 14 & 7 & 7 & 10 & 3 & 1 & 3 & 5 & 1 & 1 & 4 & 2 & 1 & 5 \\
\hline $\begin{array}{l}\text { Buy Local Supporting } \\
\text { Communities and } \\
\text { Protecting the } \\
\text { Environment }\end{array}$ & 15 & 9 & 6 & 6 & 5 & 4 & 1 & 2 & 3 & 7 & / & 4 & 1 & 3 \\
\hline Total & 138 & 68 & 70 & 67 & 41 & 29 & 22 & 44 & 31 & 19 & 18 & 34 & 14 & 53 \\
\hline
\end{tabular}


Figure 1: Shows the percentage of the four indicated characters (Gender, Age group, Advertisement and Occupation) which was adapted in this study

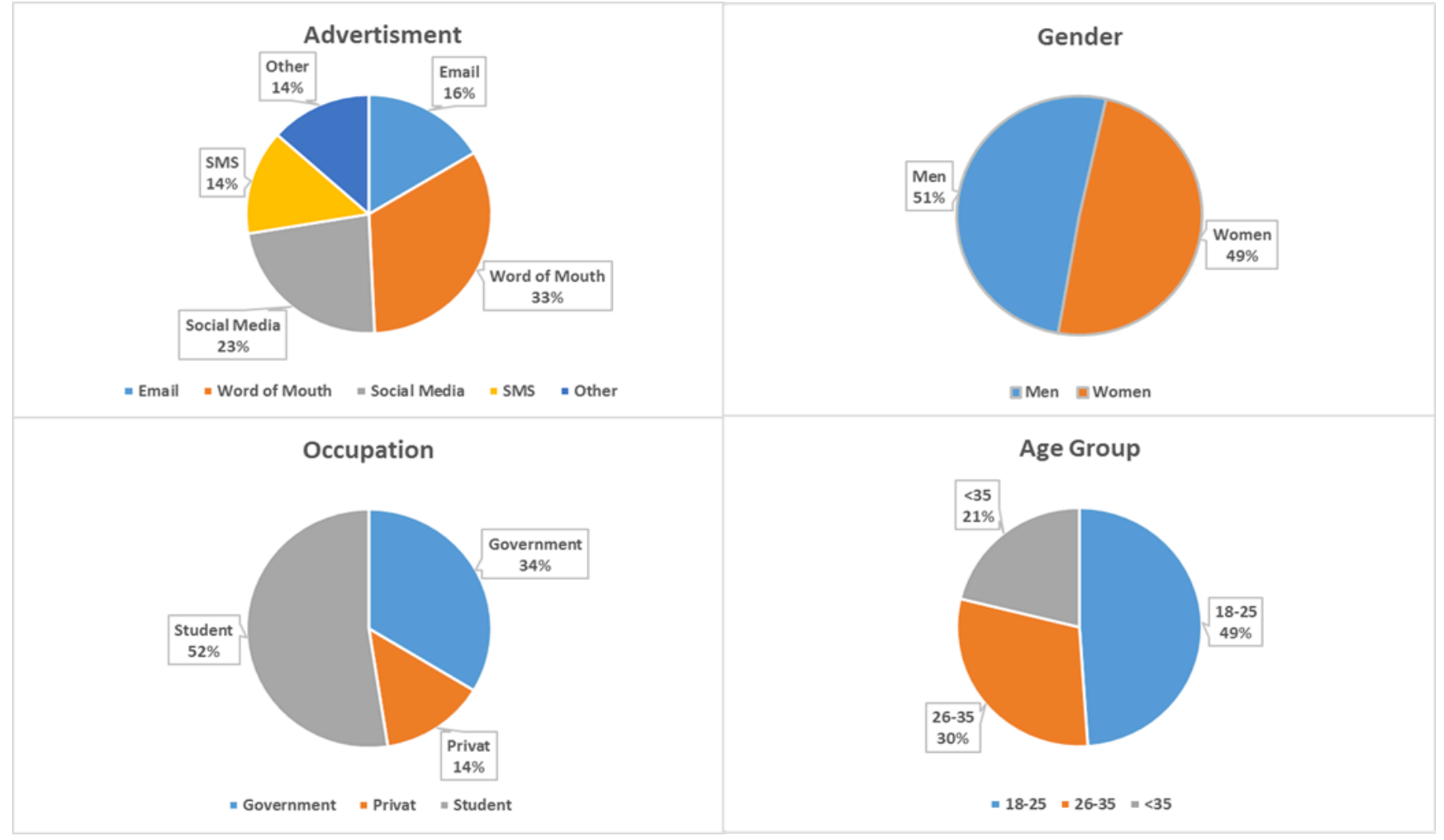

Diagram 1: The location map of science cafes around the world, and recently the Sultanate of Oman were added.

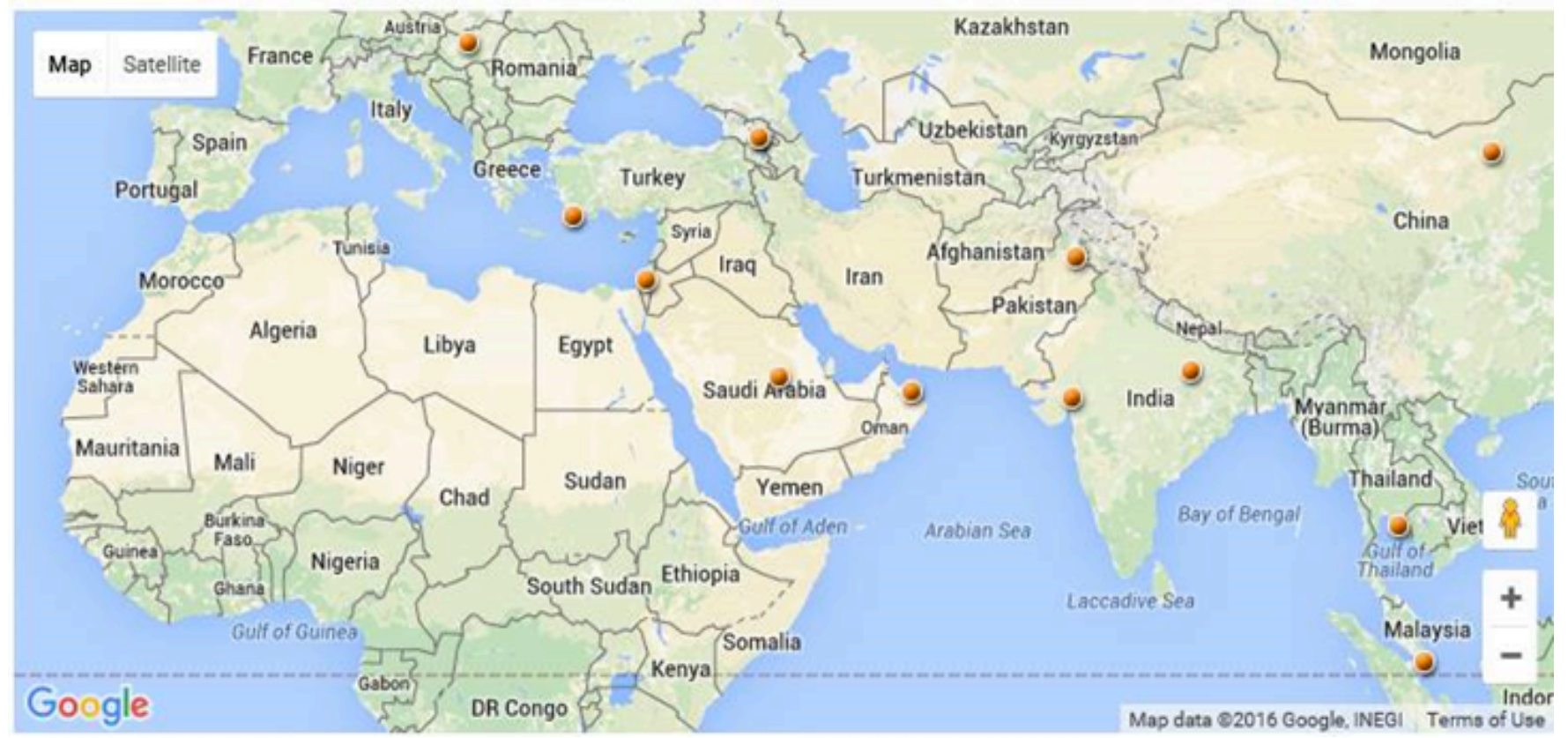

Number of sessions organized by Science Café, in diagrams 2 and 3. 
Diagram 2: Shows events posters of Science Café
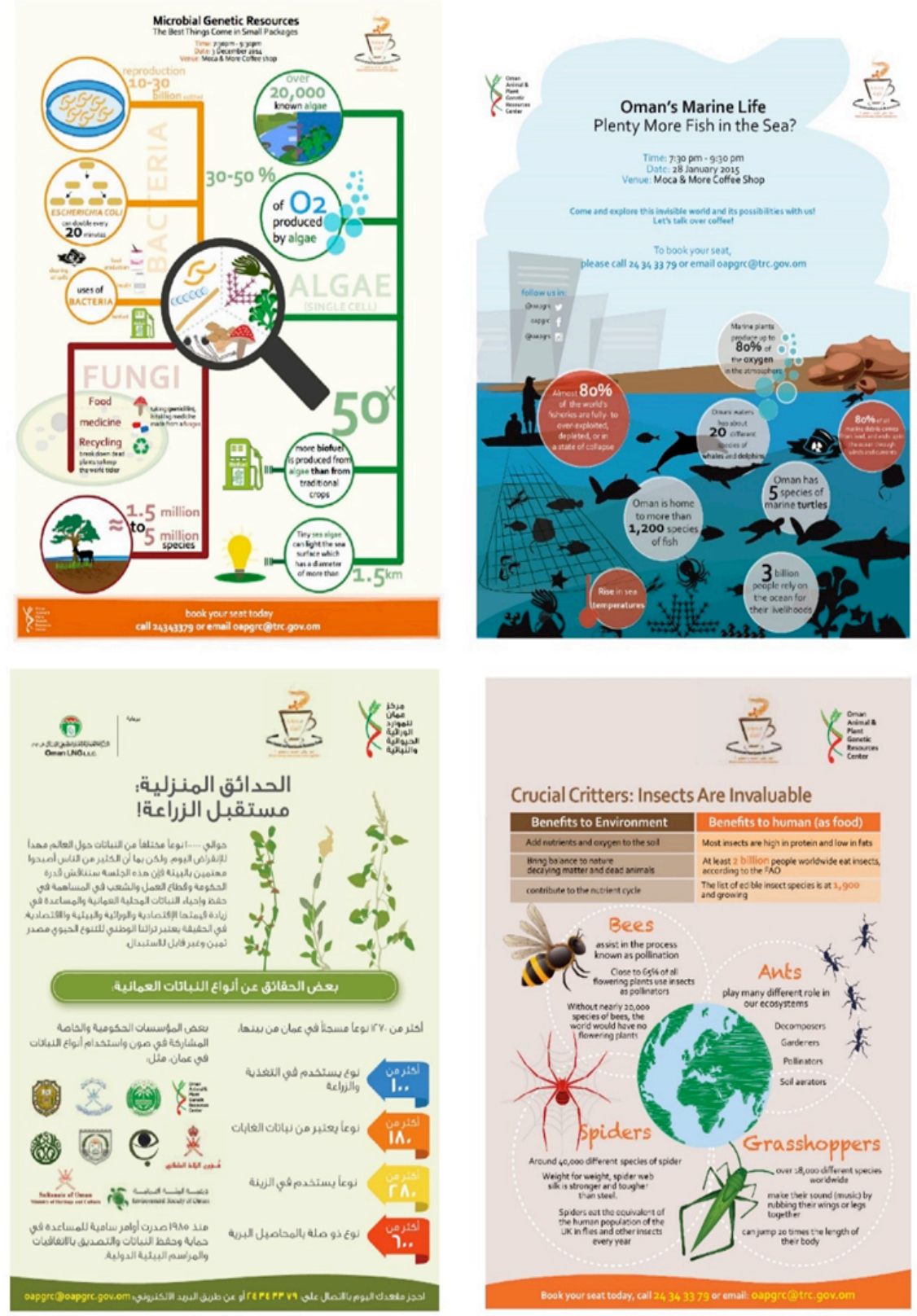
Diagram 3: Participants and discussions of Science Cafe
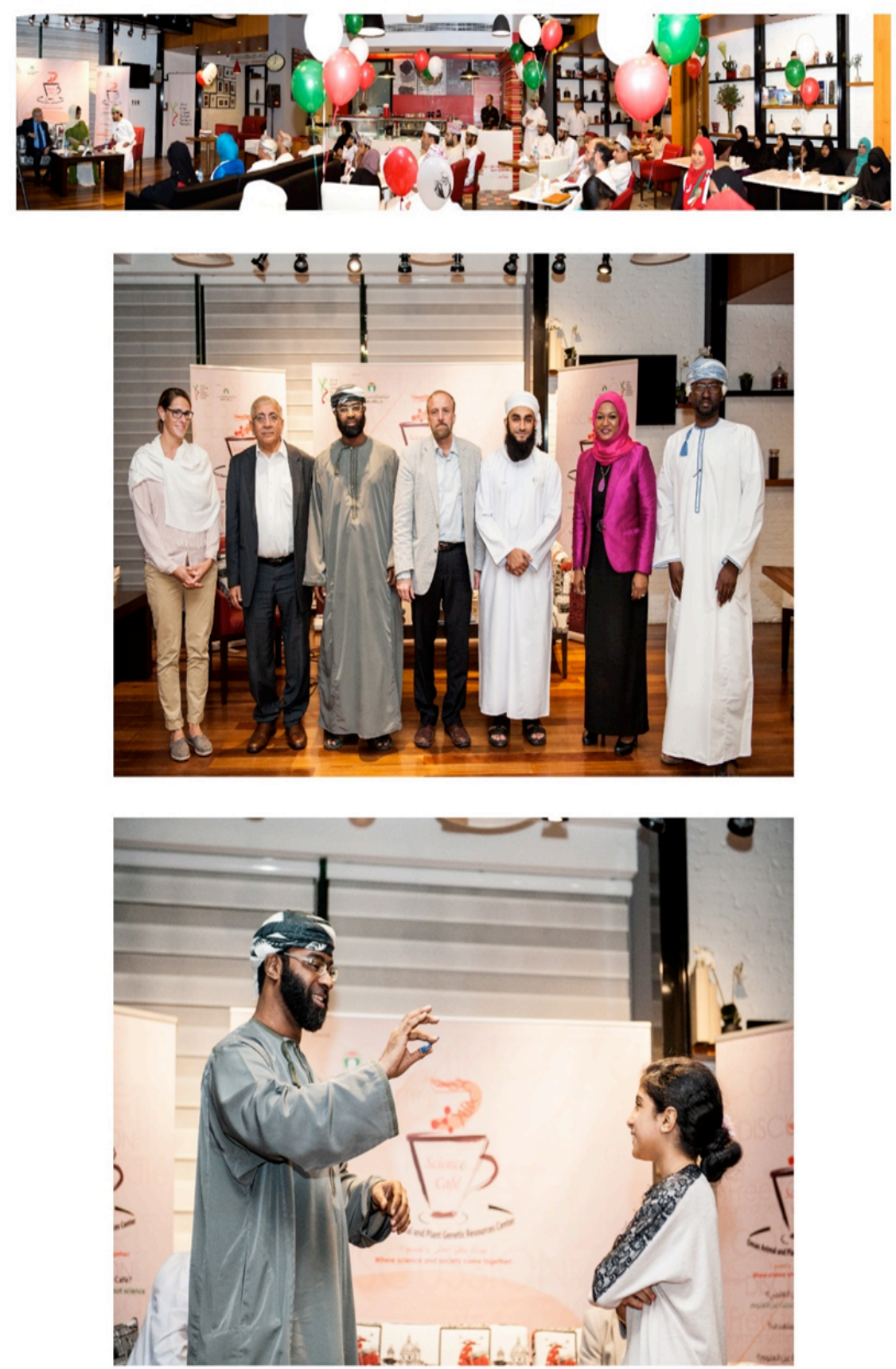


\section{References}

http://www.cafescientifique.org/index.php?option $=$ com_content\&view $=$ article\&id $=91 \&$ Itemid $=435$ Find a Café near you!

http://sciencecafes.org/find/

Junior Cafe Scientifique Scheme, Durham University (2016)

https://www.dur.ac.uk/science.outreach/outreachschemes/juniorcafescientifiquescheme/

www.juniorcafesci.org.uk

Duncan Dallas Obituary 2014 (Science), People in Science.

https://www.theguardian.com/science/2014/apr/24/duncan-dallas

Oman Animal \& Plant Genetic Resources Center (2016)

https://oapgrc.gov.om/Pages/default.aspx

https://en.wikipedia.org/wiki/Caf\%C3\%A9_Scientifique

http://sciencecafes.org/ 